\title{
Систематичний та біоморфологічний аналіз дендрофлори штучних заповідних парків Рівненської області
}

\section{Каміла Покотилова}

Національний університет біоресурсів і природокористування України, Київ, Україна Адреса для листування: каmilapg@ukr.net

Отримано: 20.09.18; прийнято до друку: 26.10.18; опубліковано: 26.12.18

Резюме. У статті наведено результати аналізу розподілу видового складу дендрофлори штучних заповідних парків Рівненської області за систематичним положенням та за життєвими формами. Установлено, що в межах цієї області розміщено 25 таких об'єктів. Із них 14 - у поліській частині області, а 11 - у зоні широколистяних лісів. На території досліджуваних об'єктів виявлено 481 вид деревних рослин (9,52\% Pinophyta, 90,48 \% Magnoliophyta). Як загалом у всіх парках, так і окремо в об'єктах, що наявні в межах двох частин області (Українського Полісся та зони широколистяних лісів), найбільшою кількістю родів та видів представлена родина Rosaceae. У результаті розподілу видів за біоморфотипами виявлено види, які належать до трьох типів: дерева, чагарники та деревні ліани. При цьому для дендрофлори штучних заповідних парків Рівненської області характерне переважання дерев Magnoliophyta. Відмінність біоморфологічної структури парків, розміщених в обох частинах області, прослідковується при розподілі видів за класами висоти: дендрофлора поліських об'єктів дослідження представлена більшою кількістю дерев четвертої висоти, а серед чагарників переважають високі, у штучних заповідних парках іншої частини області переважна кількість видів дерев належать до першого класу висоти, тут чагарники здебільшого середньої висоти. Загалом у всіх об'єктах дослідження переважають види життєвої форми мезофанерофіти, які становлять 44,30 \% у північних та 59,63\% - у південних об'єктах.

Ключові слова: дендрофлора, зона широколистяних лісів, Українське Полісся, родина, вид деревних рослин, життєва форма, клас висоти, мезофанерофіти.

\section{Systematic and Biomorphological Analysis of Dendroflora of Artificial Protected Parks of the Rivne Region}

\section{Kamila Pokotylova}

National University of Life and Environmental Sciences of Ukraine, Kyiv, Ukraine

Correspondence: Kamilapg@ukr.net

\begin{abstract}
The article presents the results of analysis of distribution of the dendroflora species composition of the Rivne region artificial protected parks by systematic situation and life forms. There are 25 artificial protected parks in the studied region. 14 of them are located in the Polissya region, and 11 in the broadleaf forests zone. There are 481 species of tree plants (9,52\% Pinophyta, 90,48\% Magnoliophyta) on the territory of investigated objects. As in general, in all parks, and separately, in the objects located within the two parts of the region (Ukrainian Polissya and broadleaf zone), the largest number of genera and species represent the family Rosaceae. As a result of classification of species by biomorph types, three types of species have been identified: trees, shrubs and wood vines. The prevalence of the Magnoliophyta trees is typical for the dendroflora of artificial protected parks of the Rivne region.

The difference in the biomorphological structure of the parks located in both parts of the area is observed in the distribution of species by classes of height. There are more trees of the fourth height and high shrubs in the dendroflora of Polissya study objects. The majority of species of trees belong to the first class of height with shrubs being mostly of average height in artificial protected parks in the other part of the region.
\end{abstract}


In general, species of mezophanerophytes life form prevail in the dendroflore of all objects of study $(44,30 \%$ in northern objects and 59,63\% in southern objects of research).

Key words: dendroflora, broadleaf forest zone, Ukrainian Polissya, family, species of tree plants, life-forms, class of height, mezophanerophytes.

\section{Вступ}

Мережа штучних об'єктів природнозаповідного фонду України має надзвичайно важливе значення для збереження водночас автохтонного та інтродукованого дендрорізноманіття. Тому дослідження дендрофлори штучних заповідних парків Рівненської області є актуальними, оскільки досі не відомо про кількісний i якісний склад видів деревних рослин цих парків. Зважаючи на те, що північна частина області лежить у межах Українського Полісся, а південна - у межах зони широколистяних лісів України, доцільно провести порівняльний аналіз систематичної та біоморфологічної регіональних структур дендрофлори штучних заповідних парків Рівненської області.

Як відомо, флористичний аналіз є класичним методичним прийомом у флорології й дендрології. Тому його застосовують як зарубіжні, так і вітчизняні вчені. Із зарубіжних дослідників вивченням дендрофлори різних парків, наприклад Хорватії, займалися Д. Тафра, М. Пандза, М. Мілович [10], Польщі - М. Дудкевич, М. Дабскі, В. Дурлак [11], Болгарії- А. Ташев, Є. Тсавков [12] та ін.

В Україні також багато праць на цю тему. Зокрема, аналізу систематичної й біоморфологічної структури дендрофлори заповідних парків приділяли увагу, наприклад у Чернівцях Н. В. Михайлович [4], в Одесі О. М. Попова, В. О. Кузнєцов, Л. П. Осадча [2], у Херсоні - Т. О. Бойко [9], на Вінниччині Н. О. Сиплива [7], загалом у степовій зоні А. С. Власенко [3] та ін.

У межах Українського Полісся подібний аналіз заповідної дендрофлори, у тому числі їі раритетної фракції, здійснили А. М. Савоськіна [8], Л. О. Коцун - для парків-пам'яток садовопаркового мистецтва Волинського Полісся) [1], Ф. Ф, Марков - для парків цієї ж категорії ПЗФ Житомирщини) [6]. Варто відзначити й спеціальну публікацію О. М. Курдюка, М. О. Гричук, М. В. Лазарець і В. А. Островської [5] для Березнівського дендрологічного парку.

\section{Матеріали й методи досліджень}

Мета роботи - установлення систематичної та біоморфологічної структури дендрофлори штучних заповідних парків Рівненської області для вироблення рекомендацій щодо успішного збереження наявних у них видів деревних рослин, передусім раритетних. Об'єкт досліджень - автохтонна та інтродукована дендрофлора штучних заповідних парків Рівненської області.

Науковими полігонами наших досліджень були 25 штучних заповідних парків чотирьох категорій природно-заповідного фонду України (парки-пам'ятки садово-паркового мистецтва, штучні пам'ятки природи, зоологічний та дендрологічний парки).

Матеріалом для флористичного аналізу слугував список видів деревних рослин (дерев, чагарників, деревних ліан, напівчагарників, чагарничків, напівчагарничків), який формували на основі низки літературних джерел і результатів власних інвентаризаційних польових досліджень протягом 2015-2018 років.

3i спеціальних методів застосований систематично та біоморфологічний аналіз дендрофлори. Перший проведено на основі методики, яка традиційно використовується в подібних дендрофлористичних дослідженнях [13], а другий - на основі аналітичних підходів О. А. Калініченка й Х. Раункієра $[13 ; 14]$.

\section{Результати}

У Рівненської області відомі 14 парків пам'яток садово-паркового мистецтва («Антонівка», Великомежиріцький, Городоцький, Гощанський, Зірненський, Клеванський, Мізоцький, Млинівський, Новоставський, Олександрійський, Острожецький, Острозький, Рівненський i Тученський). Їх дендрофлора складена 133 видами рослин. Із цих парків сім розміщено в зоні широколистяних лісів, де виявлено 118 видів, а більшість їх - у поліській частині області, у якій інвентаризовано дещо меншу кількість (96) видів деревних рослин.

Мережу штучних пам'яток природи Рівненської області формують дев'ять об'єктів («Дендропарк Острозького держлісгоспу», Більський, Висоцький, Радивилівський, Рокитнівський, Сарненський дендропарки та Володимирецький, Зарічненський i Трипутнянський парки). На цих територіях виявлено 115 видів деревних рослин. Відповідно, у зоні широколистяних лісів області нарахували лише три об’єкти цієї 
категорії (разом - 52 види). Поліська частина області вирізняється удвічі більшою кількістю об'єктів природно-заповідного фонду України цієї ж категорії, тому закономірно піi дендрофлору становлять 111 видів деревних рослин.

Рівненський зоологічний парк розміщено в зоні широколистяних лісів. Його дендрофлора утворена 65 видами деревних рослин. За даними О. М. Курдюка та співавторів [5], у Березнівському дендрологічному парку поліської частини області нараховується 461 вид деревних рослин. Звідси можна вважати, що заповідна дендрофлора Рівненської області повною мірою представлена в цьому дендропарку. Отже, загалом дендрофлора зони широколистяних лісів Рівненської області нараховує 481 вид рослин, які належать до 113 родів, 42 родин та двох відділів (табл. 1).

У складі Pinophyta виявлено лише чотири родини (Gingoidaceae, Pinaceae, Cupressaceae, Taxaceae). Кількість родів у Pinaceae та Cupressaceae однакова (по шість). Gingoidaceae й Тахасеае мають по одному роду.

Установлено, що в спектрі родин Magnoliophyta перші позиції за кількістю родів займають Rosaceae (24 роди) i Fabaceae (12 родів). Три родини (Betulaceae, Caprifoliaceae, Oleaceae) мають по чотири роди, дві родини (Hydrangeaceae та Fagaceae) по три роди, 14 родин - по два роди й 17 родин - по одному роду. Провідними родинами за кількістю видів виступають Rosaceae (109 видів), Betulaceae (35 видів) та Fabaceae (29 видів), Salicaceae (26 видів), Oleaceae (23 види), Caprifoliaceae (22 види), Hydrangeaceae (19 видів), Berberidaceae (16 видів), Sapindaceae (16 видів).

Далі відзначимо регіональні особливості систематичної структури дендрофлори штучних заповідних парків Рівненської області. Зокрема, у поліській частині нараховується 474 види деревних рослин, які належать до двох відділів, 41 родини, 113 родів (табл. 2).
Більшість становлять покритонасінні - 87,55\%, голонасінні, відповідно, мають лише 12,45\%.

Відділ Pinophyta включає чотири родини (Pinaceae, Cupressaceae, Taxaceae, Gingoidaceae). До першої з них належать шість родів та 42 види; до другої - також шість родів, проте значно менша кількість видів (лише 14). Taxaceae представлена одним родом та двома видами. Gingoidaceae має лише один рід й один вид рослин. До Magnoliophyta належить 416 видів рослин. Установлено, що Rosaceae найчисельніша за кількістю родів і видів (відповідно 24 та 108). Наступними за чисельністю є Fabaceae (12 родів, 28 видів), Betulaceae (чотири роди, 35 видів), Oleaceae (чотири роди, 23 види) i Caprifoliaceae (чотири роди, 22 види). Hydrangeaceae та Fagaceae мають по три роди, однак за кількістю видів переважає перша родина, у якій нараховується 19 видів, коли в другій - 16 видів. По два роди мають 14 родин, по одному - 16 родин.

Дендрофлора штучних заповідних парків зони широколистяних лісів Рівненської області представлена 127 видами, 73 родами й трьома родинами. Лише 18 видів рослин віднесено до Pinophyta (14,2 \%). Ці види належать до трьох родин та восьми родів. Найбільш репрезентована Pinaceae, яка має п'ять родів (Pinus L., Pseudotsuga Carriere, Larix Mill., Picea A. Dietr., Abies Mill.) та 12 видів. До Cupressaceae належать два роди (Thuja L., Juniperus L.) та чотири види. Одним родом (Taxus L.) і двома видами репрезентовано Taxaceae. Magnoliophyta охоплює 30 родин, 65 родів та 109 видів. Серед родин найбільшою кількістю родів і видів вирізняються також Rosaceae (13 родів, 22 види) і Fabaceae (сім родів, дев'ять видів). Одна родина (Betulaceae) включає чотири роди й вісім видів, три родини (Oleaceae, Fagaceae та Hydrangeaceae) мають по три роди та, відповідно, сім, чотири й три види. Sapindaceae i Adoxaceae мають по два роди та, відповідно, сім і два види, по одному роду та одному виду - 16 родин.

Таблиця 1

Кількісний таксономічний склад відділів дендрофлори штучних заповідних парків Рівненської області

\begin{tabular}{|c|c|c|c|c|c|c|}
\hline \multirow{2}{*}{ Відділ } & \multicolumn{2}{|c|}{ Родина } & \multicolumn{2}{c|}{ Рід } & \multicolumn{2}{c|}{ Вид } \\
\cline { 1 - 7 } & число, шт. & число, \% & число, $\boldsymbol{\text { шт. }}$ & число, \% & число, шт. & число, \% \\
\hline Pinophyta & 4 & 9,52 & 14 & 12,39 & 60 & 12,47 \\
\hline Magnoliophyta & 38 & 90,48 & 99 & 87,61 & 421 & 87,53 \\
\hline Разом & $\mathbf{4 2}$ & $\mathbf{1 0 0}$ & $\mathbf{1 1 3}$ & $\mathbf{1 0 0}$ & $\mathbf{4 8 1}$ & $\mathbf{1 0 0}$ \\
\hline
\end{tabular}


Систематичний та біоморфологічний аналіз дендрофлори штучних заповідних парків Рівненської області

На територіях штучних заповідних парків Рівненської області всі деревні рослини представлено видами трьох типів життєвих форм: дерева - 257 видами $(53,43 \%)$, чагарники - 214 видами $(44,49 \%)$, деревні ліани - 10 видами $(2,08 \%)$ (рис. 1$)$.

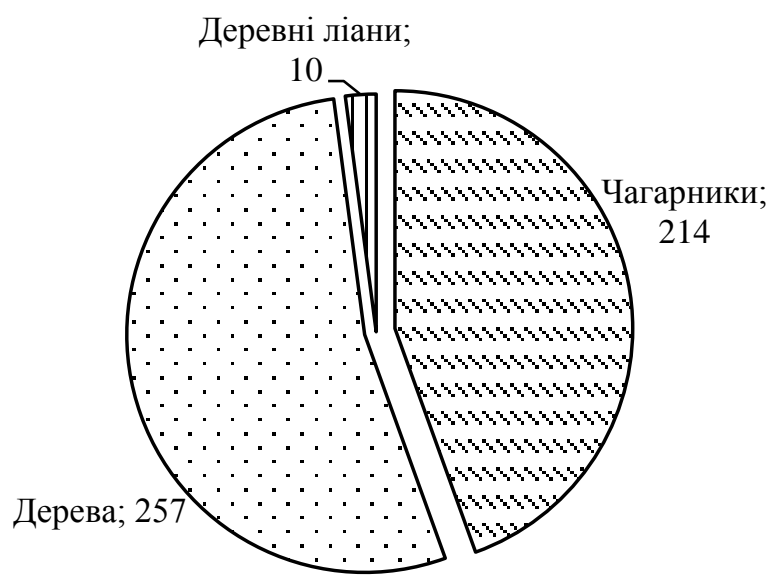

Рис. 1. Кількісний спектр біоморфотипів дендрофлори штучних заповідних парків Рівненської області

Тип дерев утворений чотирма класами висоти: першим - 101 вид (Ginkgo biloba L., Picea omorica (Pancic) Purk., Castanea sativa Mill. й ін.), другим - 20 видів (Pinus banksiana Lamb., Acer negundo L., Populus tremula L. й ін.), третім - 35 видів (Abies balsamea (L.) Mill., Platycladus orientalis (L.) Franco, Alnus glutinosa (L.) P. Gaerth й ін.) і четвертим - 101 вид (Catalpa bignonioides Walt., Rhamnus cathartica L., Sorbus aucuparia L. й ін.). Серед чагарників виявлено також три класи висоти: високі - 83 види (Juniperus communis L., Lonicera tatarica L., Viburnum opulus L. й ін.), середні - 96 видів (Juniperus sabina L., Aronia melanocarpa (Michx.) Elliot, Ribes aureum Pursh й ін.) і низькі - 34 види (Juniperus horizontalis Moench., Cotoneaster horizontalis Decaisne, Genista tinctorica L. й ін.). $\mathrm{y}$ цьому контексті дуже подібні результати отримано для дендрофлори штучних заповідних парків поліської частини Рівненської області.

Натомість у дендрофлорі штучних заповідних парків зони широколистяних лісів Рівненської області до біоморфотипу «дерева» віднесено 87 видів: класу першої висоти -43 , другої - шість, третьої - дев'ять і четвертої 29 видів рослин. Серед чагарників переважають високі (19 видів), із середніх чагарників виявлено 13 видів рослин, а 3 низьких - лише три. Дендрофлора штучних заповідних парків поліської частини в спектрі біоморфотипів дуже близька загальним показникам: до класу дерев першої висоти належить 97 видів, другої - 20, третьої - 34 та четвертої - 99. Виявлені тут чагарники належать до трьох класів висоти: високих (83 види), середніх (96 видів) і низьких (35 видів).

Загалом по всіх об'єктах досліджень за кількістю на першому місці виявилися види біоморфотипу «чагарники» Magnoliophyta (Aronia melanocarpa (Michx.) Elliot, Cotoneaster lucidus Schltdl., Ribes aureum Pursh й ін.), наступну ланку зайняли покритонасінні типу «дерева» (Acer saccharinum L., Catalpa bignonioides Walt., Quercus pubescens Willd. й ін.), далі - тип «дерева» Pinophyta (Larix kaempferi (Lamb.) Carriere, Pinus peuce Griseb., Taxus baccata L. й ін.), тип «деревні ліани» Magnoliophyta посідає передостанне місце (Celastrus orbiculatus Thunb., Parthenocissus quinquefolia (L.) Planch., Vitis amurensis Rupr. й iн.), найменшу частку становлять голонасінні типу «чагарники» (Juniperus communis L., Juniperus horizontalis Moench., Juniperus squamata Buch.-Ham. ex D. Don та ін.). Такі самі дані виявлено в дендрофлорі північних об'єктів дослідження.

Дещо інша картина розподілу біоморфотипів дендрофлори в південних об'єктах області: більшість - покритонасінні види дерев, майже удвічі менша кількість - чагарники цього ж відділу, наступні ланки - дерева Pinophyta та деревні ліани Magnoliophyta, найменше представлені голонасінні чагарники.

За класифікацією X. Раункієра, усі досліджувані види рослин належать до однієї групи життєвих форм, тобто фанерофітів (нано-, мікро-, мезо- та мегафанерофітів). Нанофанерофіти становлять $16,42 \%$ від загальної кількості, із них 96,20\% покритонасінні рослини (Juniperus horizontalis Moench., Berberis aquifolium Pursh, Cotoneaster horizontalis Decaisne й ін.). Серед мікрофанерофітів виявлено лише види Magnoliophyta (27,65\%, Deutzia scabra Thunb., Spiraea salicifolia L., Ribes aureum Pursh й ін.). Група мезофанерофітів найбільш репрезентована $(44,91 \%$, Platycladus orientalis (L.) Franco, Thuja occidentalis L., Sorbus alnifolia (Siebold \& Zucc.) K. Koch й ін.), у ній 87,50 \% покритонасінних рослин. До мегафане- рофітів належить найменша частка видів деревних рослин (11,02\%, Abies concolor Lindl. et Gord., Pinus sylvestris L., Platanus orientalis L.), здебільшого це голонасінні (56,60 \%) (рис. 2).

Значне переважання мезофанерофітів 


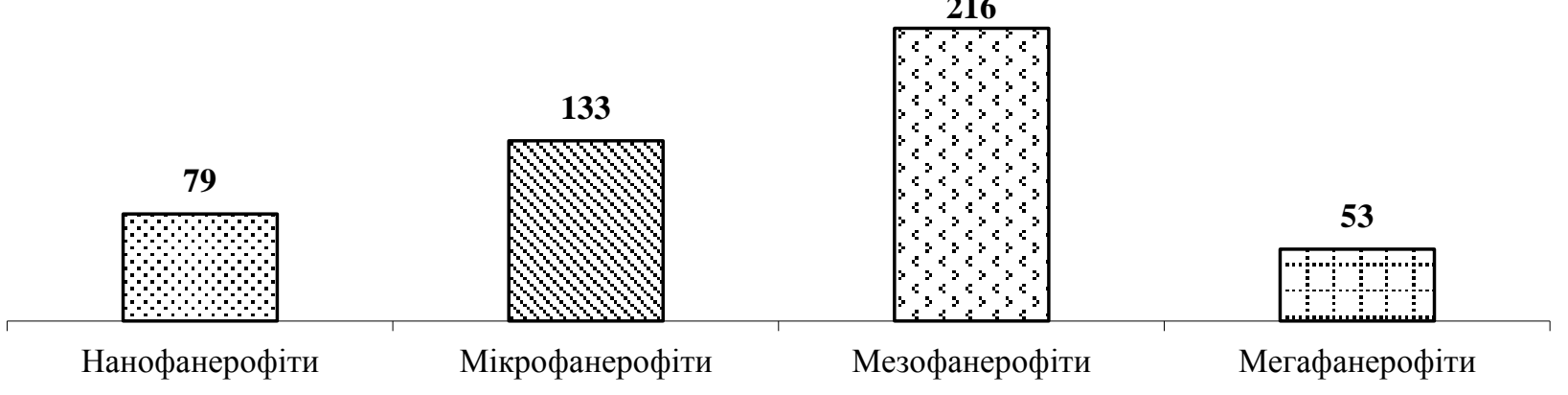

Рис. 2. Кількісний спектр видів фанерофітів дендрофлори штучних заповідних парків Рівненської області

також характерне для обох частин області. У штучних заповідних парках зони широколистяних лісів група мезофанерофітів становить $59,06 \%$, i3 них $59,63 \%$ Magnoliophyta (Acer campestre L., Carpinus betulus L., Morus alba L. та ін.), решта Pinophyta (Larix polonica Racib., Pinus pallasiana D. Don., Taxus cuspidata Siebold \& Zucc. та ін.). У поліських об'єктах області мезофанерофіти становлять $44,30 \%$, із них $87,5 \%$ покритонасінні види рослин (Alnus glutinosa (L.) P., Quercus robur L., Tilia tomentosa Moench. й ін.), решта - голонасінні (Abies balsamea (L.) Mill., Juniperus virginiana L., Taxus cuspidata Siebold \& Zucc. та ін.).

\section{Обговорення}

Отримані результати дослідження свідчать про значну відмінність дендрофлори штучних заповідних парків двох частин області, яка полягає в різній кількості видів деревних рослин - у поліських об'єктах дослідження виявлено 474 види, коли дендрофлора досліджуваних об'єктів у межах зони широколистяних лісів складається зі 127 видів. Проаналізувавши отримані результати досліджень, звертаємо увагу на те, що природні умови поліської частини Рівненської області, порівняно з частиною зони широколистяних лісів, менш сприятливі для хорошого росту та розвитку більшої кількості виявлених нами видів рослин. Однак у поліській частині області завдяки Березнівському дендрологічному парку значно ширший видовий склад деревних рослин, який уключає майже всі види, які виявлено в штучних заповідних парках зони широколистяних лісів у межах області загалом.

На досліджуваних територіях простежуємо переважання видів дерев Pinophyta над чагарниками того ж відділу (відповідно, 93,22 та 6,78\% від загальної кількості видів дерев відділу). Magnoliophyta представляють види дерев $(49,76 \%)$, чагарників $(47,87 \%)$ i деревних ліан $(2,37 \%)$. Зауважимо, що на території всіх штучних заповідних парків області значно переважають види деревних рослин життєвої форми «мезофанерофіти»

\section{Висновки}

Загалом дендрофлора штучних заповідних парків Рівненської області складається 3 481 виду, 113 родів, 42 родин і двох відділів. Кількісно значно переважають види Magnoliophyta, де найбільш представлено Rosaceae. Виявлені види деревних рослин належать до трьох типів життєвих форм: дерева $(53,43 \%)$, чагарники $(44,49 \%)$ та деревні ліани $(2,08 \%)$. За класами висоти переважають дерева першої й четвертої висоти, серед чагарників - середньовисокі. Установлено, що більшість видів дендрофлори штучних заповідних парків Рівненської області формують покритонасінні види типу життєвої форми «чагарники». Дендрофлору штучних заповідних парків репрезентовано видами нано-, мікро-, мезо- й мегафанерофітів. Із них найбільш поширена група мезофанерофітів.

\section{Література}

1. Коцун, Л. О. Парки-пам'ятки садовопаркового мистецтва Волинського Полісся. Науковий вісник Волинського державного університету імені Лесі Украӥнки; 2007, 11, с 162-166.

2. Попова, Е. Н.; Кузнецов В. О.; Осадчая Л. П. Дендрофлора парков-памятников садово-паркового искусства города Одессы. Научные записки Государственого природо ведческого музея; 2007, 23, с 145-156.

3. Власенко, А. С. Заповідна дендросозофлора $E X S I T U$ Степу України. Дис. на здобуття наук. ступеня канд. біол. наук: спец. 06.03.01. Київ, Національний університет біоресурсів $i$ природокористування Украӥни; 2016, 229 с. 
Систематичний та біоморфологічний аналіз дендрофлори штучних заповідних парків

Рівненської області

4. Михайлович, Н. В. Структурний аналіз дендрофлори парку-пам'ятки садово-паркового мистецтва «Чернівецький парк культури i відпочинку ім. Т. Г. Шевченка». Науковий вісник Національного університету біоресурсів $i$ природокористування України; 2014, 1, с 175-180.

5. Курдюк, О. М.; Гричук, М. О.; Лазарець, М. В.; Островська, В. А. Таксономічний склад і структура насаджень дендрологічного парку Березнівського лісового коледжу. Науковий вісник Наиіонального університету біоресурсів і природокористування України; 2015, 1, с 186-175.

6. Марков, Ф. Ф. Структура насаджень i територіальна організація старовинних парківпам'яток садово-паркового мистецтва Житомирщини. Автореф. дис. канд. с.-г. наук: спец. 06.03.01. Київ, Житомирський державний агроекологічний університет, 2015, 20 c.

7. Сиплива, Н. О. Інвентаризаційні дослідження парків-пам'яток садово-паркового мистецтва Вінниччини. Вісник Національного науково-природничого музею; 2014, 12, с 116-122.
8. Савоськіна, А. М. Біоморфологічна та екологічна структура екзотичної дендросозофлори штучних заповідних парків Українського Полісся. Науковий вісник Східноєвропейського начіонального університету імені Лесі Украӥнки; 2016, 7, с 59-65.

9. Boiko, T. O.; Dementieva, O. I. The tree vegetation of the Kherson State Agrarian University Arboretum. Ukrainian journal of ecology; 2018, 8 (2), pp 120-127.

10. Tafra D.; Pandza M.; Milovic M. Woody plants of the Omis. The nature of Croatia; 2012, 2, pp 301-334.

11. Dudkiewicz M.; Dudkiewicz M.; Dabski M., Durlak W. Dendroflora zabytkowego parku w Kijanach. Formatio circumiectus; 2015, 14, pp 15-25.

12. Tashev A.; Tsavkov E. Dendroflora of calcareous terrains in Bulgaria and its significance for conservation. Nature Conservation Research; 2016, 1, pp 70-77.

13. Калініченко, О. А. Декоративна дендрологія: Навч. посіб. Вища шк.: Київ, 2003, 200 с.

14. Raunkiaer C. Plant life forms. Oxford, 1937, $104 \mathrm{p}$. 